\title{
Generation Y Consumer Shopping Styles: Evidence from South Africa
}

\author{
Lawrence Mandhlazi \\ Lecturer: Vaal University of Technology \\ Private Bag X021, Vanderbijpark, 1900 \\ Email: lawrencem.@vut.ac.za \\ Manilall Dhurup \\ Executive Dean: Vaal University of Technology \\ Private Bag X021, Vanderbijpark, 1900 \\ Email: royd@vut.ac.za \\ Chengedzai Mafini \\ Vaal University of Technology \\ Private Bag X021, Vanderbijlpark, 1900 \\ Email: chengedzai@hotmail.com
}

Doi:10.5901/mjss.2013.v4n14p153

\section{Abstract}

The buying behaviour of Generation $Y$ consumers has been a marketing concern for many marketers and researchers. This has led to an avalanche of research efforts seeking to provide information on how best marketers can sell their products to these elusive consumers in unpredictable markets. The study served two purposes: to investigate the purchasing shopping styles of Generation Y consumers and to determine whether there are any variations with regard to age in these shopping styles. The study was undertaken within the context of the fashion apparel market in South Africa. The study employed a quantitative approach in which a structured questionnaire was used to survey a sample of 230 conveniently selected Generation $Y$ consumers. The study employed exploratory factor analysis to identify Generation $Y$ shopping styles and Analysis of Variance (Anova) to examine the influence of age. Seven shopping styles that are applicable to the Generation $Y$ cohort were identified, described as: quality conscious, brand conscious, novelty seeking, hedonistic, confused by overchoice, habitual and brand loyal, and fashion conscious. Younger consumers were found to be more confused by overchoice than their older counterparts. These findings may enable marketers to understand and predict the purchase behaviour of Generation $Y$ consumers, thereby facilitating the development and implementation of more effective marketing strategies.

Keywords: Generation Y, Shopping styles, Fashion apparel market, South Africa

\section{Introduction}

Generation Y consumers have emerged as a significant force in the global marketplace (Noble, Haytko \& Phillips, 2009). This is mainly because they are in the marketplace in large numbers and possess the purchasing power to outperform any other group of consumers (Morton, 2002). Generation $Y$ individuals have grown up in a consumption-driven contemporary society and have more money at their disposal than any teen group in history (Kennedy, 2001). This makes them arguably the largest group of consumers in any economy (Chaston, 2009). Because of its size and spending power, Generation $Y$ deserves close attention from both the marketing practitioners and empirical researchers (Branchik, 2010).

Since not every generation is alike, it is of paramount importance that marketers treat individuals and groups of different age cohorts differently (Rempel, 2009). In finding new ways to market to Generation $Y$, it is imperative for marketers to have a clear and distinct conceptualisation of these consumers, by being constantly aware of the changing attitudes and trends in this generation (Hughes, 2008). The rapidity of change in technology makes it necessary to study the consumer behaviour of Generation $Y$ continuously because, as soon as one thinks that one may have an understanding of what this generation wants, those wants will have changed (Kaltcheva \& Weitz, 2006). Generation $Y$ 
consumers are very likely to spend their cash as quickly as they acquire it, usually on consumer goods and personal services (McKay, 2008). Compared with their predecessors, members of Generation $Y$ are more likely to be involved in compulsive and impulse buying (Rosenburg, 2008). Moreover, in their desire for uniqueness, they are generally inclined to distrust the stores that their parents shop in (Branchik, 2010).

In recent times, generational cohorts have emerged as a constructive tool in delineating emerging patterns in buying behaviour among various consumer groups. A generational cohort is a constellation of individuals who have experienced a common social, political, historical and economic environment (Neal, Quester \& Hawkins, 2004). This development has led to the emergence and widespread use of the phrase "Generation Y" to identify a group of individuals born between 1980 and 1994 (Schiffman \& Kanuk, 2010). Generation Y individuals are also labelled the Millennium Generation, Echo Boomers, Why Generation, Net Generation, Gen Wired, We Generation, DotNet, $\mathrm{Ne}(\mathrm{x}) \mathrm{t}$ Generation, Nexters, First Globals, iPod Generation, and iYGeneration (Koutras, 2006; Williams \& Page, 2011).

Generation $Y$ individuals were born during the era when countries could easily communicate with one another, especially with the emergence of direct means of communication, which is characterised by a powerful convergence towards materialism (Cant, Brink \& Brijball, 2006). Generation $Y$ can be further divided into three sub-segments, namely adults of 18 to 27 years old, teenagers 13 to 17 years old and children 8 to 12 years old (Martin \& Turley, 2004). Generation $Y$ individuals are far more diverse than the generations before them, because they have extreme confidence, awareness and individuality (Laermer \& Simmons, 2007). They also have a more optimistic outlook and are more socially conscious and open to new experiences (Truman, 2007). They exhibit the desire to be in constant connection and communication with their peers (Cortes, 2004). This generation, contrary to popular belief, leads a relatively quiet life of listening to music and hanging out with friends (Bush, Martin \& Bush, 2004). They have also moved some of their television viewing habits to the Internet and are less likely to read the newspaper than their parents are (Cant et al., 2006).

It is against this backdrop that this study ventures to explore the shopping styles that are applicable to Generation $Y$ consumers. For the purposes of the current study, shopping styles of Generation $Y$ consumers were considered within the ambit of the fashion apparel market. There is a specific reason why this market was selected. The fashion apparel context was selected because of the insatiable appetite for fashion apparel manifested in Generation $Y$ consumers (Wiliiams \& Page, 2011). Because of their fashion consciousness, Generation Y consumers typically spend two-thirds of their income on fashion apparel (Bakewell \& Mitchell, 2003; Kim \& Park, 2005). A number of research studies (Schewe \& Meredith, 2004; Chaston, 2009; Liljander, Polsa \& van Riel, 2009; Pentecost \& Lynda, 2010), which were conducted in varied contexts acknowledge that Generation $Y$ consumers tend to be more fascinated by fashion apparel, fast foods and electronic gadgets than by other commodities. This made the fashion apparel market an appropriate environment for investigating the shopping styles of Generation Y consumers.

\section{Consumer Shopping Styles}

Research reveals that at various levels of marketing theory and practice, the consumer is central to all activities. It is critical for marketers to have an extensive knowledge of the various factors influencing consumers' decisions to ensure the successful delivery of products and the retention of customers in the marketplace (Hollywood, Armstrong \& Durkin, 2007). Shopping styles define general consumer types, such as price-oriented shoppers, problem-solving shoppers, impulse shoppers and convenience shoppers (Zeng, 2008). The shopping styles approach seeks to categorise consumers into groups or types that are related to retail patronage (Leo, Bennett \& Hartel, 2005) as well as shopping orientations (Gehrt \& Shim, 1998).

Shopping orientations are shoppers' styles that place special emphasis on certain activities (Gehrt \& Shim, 1998). Shopping orientation is recognised as a complex social, cultural and economic phenomenon (Lee, 1998). Therefore, the examination of a comprehensive relationship among key variables in determining shopping orientations would provide diagnostic value to retailers in determining market segmentation (Lee, 1998; Hou \& Lin, 2004). The basic premise of shopping orientation is that shoppers with different styles have different market behaviours, including a need for different information sources and different store preferences (Gehrt \& Shim, 1998).

The first taxonomy of consumer shopping styles was proposed by Westbrook and Black (1985), and sought to enhance the understanding of motivational-based shopper typologies of adult female shoppers in department stores. These authors identified four classifications, namely the economic consumer, the personalising consumer, the ethical consumer and the apathetic consumer. Economic shoppers were characterised by a careful approach to shopping, giving heightened attention to merchandise assortment, price and quality. Personalising shoppers appeared to seek personal 
relationships with retail personnel, while ethical shoppers were willing to sacrifice lower prices and wider selections of goods in order to behave consistently with moral beliefs. Finally, the apathetic shopper shopped largely out of necessity, with the shopping activity holding no intrinsic interest.

In contrast to the foregoing classification, the structure of which was largely determined by empirical observation of consumer shopping styles in a comparison between young consumers of United States and Korea, Hafstrom, Chae and Chung (1992) examined the taxonomy of shoppers, theirs being "perfectionism," "value consciousness," "brand consciousness," "novelty-fad-fashion consciousness," "shopping avoider-time saver-satisfier," and "confused supportseeking decision maker". In this taxonomy, perfectionist consumers seek the very best quality products, have high standards and expectations for consumer goods and are concerned with the function and quality of products. Valueconscious consumers are low price conscious, look for the best value for their money and are likely to be comparison shoppers. Brand-conscious consumers are oriented toward expensive and well-known national brands and feel price is an indicator of quality. Novelty-fad-fashion-conscious consumers gain excitement and pleasure from seeking out new things and are conscious of the new fashions and fads. Shopping avoider-time saver-satisfier consumers avoid shopping, make shopping trips rapidly and may forgo some quality for time and convenience. Finally, the confused support-seeking decision maker finds the marketplace confusing; he/she views brands as alike and seeks help from friends (Hafstrom, et al., 1992) to make decisions.

Bae (2004) distinguished eight characteristics of consumer decision-making styles: perfectionist, brand conscious, novelty/fashion conscious, recreational/hedonic, price conscious/value-for-money, impulsive/careless, confused by overchoice and habitual/loyal consumers. The perfectionist or quality-conscious consumers have a desire for high-quality products and a need to make the best or perfect choice versus buying the first product or brand that is available. The brand-conscious consumer has the desire to purchase well-known national brands, higher-priced brands and/or the most advertised brands. The novelty/fashion-conscious consumer can be defined as a shopper who is aware of new styles, changing fashions and attractive styling, as well as having the desire to buy something exciting. The recreational/hedonic consumers are shoppers who enjoy shopping as a leisure-time activity. The price-conscious consumers aspire towards the best value, buying at sale prices or the lowest price. The impulsive/careless consumers can be described as shoppers who tend to make impulsive, unplanned and careless purchases. The consumer confused by overchoice feels confused by product choices because of a proliferation of brands, stores and consumer information. Finally, the habitual/brand-loyal consumers are described as consumers who have favourite brands and whose buying habits reveal that they consistently use the same store over time (Bae, 2004).

In summary, consumers display different shopping styles, based upon their individual personalities and characteristics (Bae, 2004). They may have a unique focus when they enter a store and shop. Some consumers consider a good price and trendy fashion, while others are interested in brand names with high quality. Depending on their wants, consumers customise their shopping styles. Consumer confusion, however, often takes over when they encounter other choices immediately prior to making a specific selection (Mishra, 2010).

From the foregoing discussion, it can be concluded that there is diversity in consumer shopping styles. However, this diversity appears to be a result of researchers using different bases for conceptualising shopping orientation, and of the diversity of the retail experience and product class researched (McDonald, 1993).

\section{Research Problem}

The underlying determinants of how and why people shop has been a topic of study for many years (Bakewell \& Mitchell, 2003). In the context of Generation $Y$ consumers, research has demonstrated that individuals within this age cohort display differing shopping orientations, thereby provoking the need for more extensive empirical introspection (Jin \& Kim, 2003). More specifically, Generation $Y$ consumers have been brought up in an era when shopping has evolved from being a simple act of purchasing to a highly complex and sophisticated process (Bakewell \& Mitchell, 2003). There are at least three reasons for conducting this study. First, it is possible that Generation $Y$ consumers have developed shopping styles that are different from those of previous generations (Ma \& Niehm, 2006; Bakewell \& Mitchell, 2003). Based on that notion, it is necessary to examine if the established shopping styles are applicable to Generation $Y$ consumers as well. Second, shopping styles are an important factor to researchers and marketing practitioners alike, as evidenced through the extensive attention that the subject has received from such stakeholders. This fact suggests that they merit further research on a continuous basis in order to generate current knowledge that updates what is already known. Third, empirical evidence of this subject in the context of South African Generation Y consumers is rare. As suggested by Noble et al. (2009) there is a need to conduct more research on a regular basis to understand the trends in the fast-evolving 
Generation $Y$ market. It is therefore important that the shopping styles of Generation $Y$ consumers be investigated in order to close this gap in the research and to provide information that enables marketers to understand the behaviour of Generation $Y$ consumers. In the light of the preceding assertions, the current study sought to establish the shopping styles applicable to Generation $Y$ consumers and to determine Generation Y consumers' shopping styles differ based on their age. The study is significant in that its findings may be used to assist marketers to develop and implement strategies that are appropriate in meeting the needs of the Generation Y group of consumers.

\section{Research Methodology}

\subsection{Respondents}

The sample used in the current study was composed of 250 Generation $Y$ individuals aged between 16 and 27 years. Respondents were recruited from different shopping malls in the Kempton Park area of Gauteng Province in South Africa. Kempton Park was chosen because of its dominant economic significance to South Africa. For instance, the area boasts a multiracial society with a population of nearly 200000 people, houses the largest airport in Africa, namely OR Tambo International Airport, has a large and active industrial site and has advanced retailing infrastructure in the form of shopping malls and shopping centres (City of Ekurhuleni, 2011). Moreover, the principal researcher was based in the same locality, an element which facilitated easier collection of data. It is also interesting to note that the sample size of 250 Generation Y consumers is consistent with previous studies (Durvasula, Lysonski \& Andrews, 1993; Kim, 2003; Bakewell \& Mitchell, 2004; Kwan, Yeung \& Au, 2008; Drake-Bridges \& Burgess, 2010), in which similar sample sizes were used to investigate the behaviour of Generation Y consumers, albeit in different contexts. In addition, Generation $Y$ individuals possess the mental and cognitive capacities to respond to questionnaire-type questions (Shoham \& Dalakas, 2003).

\subsection{Data collection and measuring instrument}

In the current study, a structured self-administered survey questionnaire was used to collect the data. Structured questionnaires are advantageous in that they are versatile and facilitate the accurate collection of data, since all respondents are asked the same questions (Tustin, Ligthelm, Martin \& Van Wyk, 2005). The questionnaire was compiled using Likert scales adapted from previous relevant research studies (Gutman \& Mills, 1982; Sproles \& Kendall, 1986; Fan \& Xiao, 1998; Hafstrom et al., 1992; Durvasula et al., 1993; McDonald, 1993; Oh \& Fiorito, 2002; Bakewell \& Mitchell, 2003, Parker, Hermans \& Schaefer, 2004; Leo et al., 2005). The questions were developed on a 5-point Likert scale, anchored by 5 denoting strongly agree, 3 denoting moderately agree and 1 denoting strongly disagree. The Likert scale was utilised because it is relatively easy to construct, makes data easy to collect and analyse, thereby making it suitable for surveys (DeVellis, 2003; Kothari, 2009).

The questionnaire was divided into two sections. Section A consisted of questions related to shopping styles. Section B elicited respondents' demographic information. After its construction, the questionnaire was pretested in a conveniently selected sample of 20 respondents in order to identify and eliminate problems as well as to determine the time for the completion of the questionnaire (Presser et al., 2004). Feedback from the pretest sample was used to make minor revisions to the questionnaire (Radhakrishna, 2007). Thereafter, the questionnaire was administered on four consecutive weekends (Saturdays \& Sundays) in April 2012. Weekends were selected as they are the busiest shopping days of the week in South Africa (Bowles, 2012). The shoppers were requested to complete the questionnaires after they had completed their shopping for the day so that valid measures of the time spent could be elicited (Da-Silva, Davies \& Naude, 2002; Dhurup, 2008). Three trained undergraduate third-year marketing students from a South African university of technology assisted in the administration of the questionnaires. During the process of data collection, the research assistants were monitored on-site by the principal researcher. A covering letter which clearly specified that anonymity of the respondents would be guaranteed and that the study was purely for academic purposes was attached to the questionnaire. Of the 350 questionnaires that were initially distributed, 263 were returned. Of these, 13 were eliminated because they were incomplete, which resulted in the 250 questionnaires used in the current study.

\subsection{Analysis of results}

In the current study, the collected data were analysed using the Statistical Packages for the Social Sciences (SPSS 
Version 20.0). The empirical results obtained are presented in this section as follows: the characteristics of the sample are reported, followed by a report on the validity and reliability of the scale. The results of the factor analysis of the shopping styles of generation $Y$ consumer decision-making styles are then presented, followed by the results of the study's examination of whether there were any significant differences between the established shopping styles and the ages of respondents.

\section{Research Results}

\subsection{Sample composition}

The gender distribution in the sample indicates that out of 250 respondents, 85 were males (34\%) and 165 were females (66\%). The age group 16-20 years formed the highest percentage (49\%), followed by the age group 21-24 years (35\%) and the age group $25-27$ years (16\%). In terms of race, $86 \%$ (215) of the respondents were black, $8 \%(21)$ were white, $4 \%$ (9) were Indian and $2 \%(5)$ were coloured.

\subsection{Factor analysis}

The shopping styles of Generation Y consumers were determined using Exploratory Factor Analysis. This is a statistical technique used to identify a set of latent (hidden) constructs underlying a battery of measured variables (Norris \& Lecavalier, 2009). It was selected for the current study because it is applicable when the researcher does not have an a priori hypothesis about the factors or patterns of measured variables (Malhotra, 2009), which is the case in the current study.

To determine whether the data were suitable for a factor analysis, the Bartlett's test of Sphericity and the KeiserMeyer-Olkin (KMO) measure of sampling adequacy were conducted, as recommended by Pett, Lackey and Sullican (2003). The Bartlett's test of Sphericity was significant at $p<0.000$, from which it could be inferred that the data set was not an identity matrix with zero correlations and was suitable for factor analysis (Aldlaign \& Buttle, 2002). The KMO measure of sampling adequacy was 0.894 , which is considered satisfactory by Malhotra (2010), signifying that the data were suitable for factor analysis. The percentage of variance explained, the scree plot and eigen value criterion guided the extraction of factors. In addition, items that loaded heavily on more than one factor were eliminated from further scale development. Hence cross-loading was also examined in the factor structure. Items were eliminated either because of cross-loading or low factor loading $(<0.50)$ (Maholtra, 2007). This procedure resulted in the extraction of seven meaningful factors labelled fashion-conscious consumers, hedonistic consumers, brand-conscious consumers, noveltyseeking consumers, quality-conscious consumers, consumers who are confused by overchoice, and habitual, brand-loyal consumers.

\subsection{Reliability and validity}

The Cronbach alpha statistic was computed to assess the internal consistency of the instrument (Leo et al., 2005). Reliability tests were conducted on all 41 items. The items that had low or negative inter-item correlation were deleted. Table 1 reports on the Cronbach alpha values for the seven dimensions of Generation Y shopping styles.

The Cronbach alpha coefficients for factors 1 to 7 ranged from 0.836 to 0.961 , indicating satisfactory levels of internal consistency in terms of reliability. The seven factors reflected reliability values above the accepted benchmark of 0.70 , which, according to Hair et al., (2010), is regarded as satisfactory. In addition, the reliability of the overall scale was 0.891 , which was also considered satisfactory

Table 1: Item reliability analysis

\begin{tabular}{lcc}
\hline \multicolumn{1}{c}{ Factor } & Cronbach Alpha & No of items \\
\hline Habitual, brand-loyal consumers & 0.836 & 3 \\
Quality-conscious consumers & 0.849 & 5 \\
Brand-conscious consumers & 0.875 & 6 \\
Novelty-seeking consumers & 0.892 & 5 \\
\hline Consumers confused by overchoice & 0.898 & 4 \\
\hline
\end{tabular}




\begin{tabular}{lcc}
\hline Hedonic consumers & 0.928 & 8 \\
Fashion-conscious consumers & 0.961 & 10 \\
Overall Cronbach alpha & 0.891 & \\
\hline
\end{tabular}

Validity can be defined as the degree to which a test or instrument measures what it purports to measure (Bae 2004). Content validity was conducted in the pretest. To test for content validity, 20 respondents were chosen to participate in the pretest. The inter-item correlation was examined in order to identify low or negative correlations among variables that measured decision-making styles. Subsequently, changes were made to the questionnaire, where several items were deleted, added or re-worded in order to capture the essence of consumer decision making within the context of garment retailing. Construct validity of the scale was assessed by the computation of the Cronbach alpha coefficient for the scale and sub-dimensions of the scale, which was acceptable and an indication of construct validity (Parasuraman, Zeithaml \& Berry, 1988). In addition, factor analysis was performed on each of the seven constructs to determine the percentage of variance that is explained by each factor. Table 2 summarises the factor structure evaluation of the scale.

Table 2: Rotated Factor Loading Matrix

\begin{tabular}{|c|c|c|c|c|c|c|c|}
\hline Factors and variable descriptions & $\begin{array}{c}\text { Factor } \\
1\end{array}$ & $\begin{array}{l}\text { Factor } \\
2\end{array}$ & $\begin{array}{c}\text { Factor } \\
3\end{array}$ & $\begin{array}{c}\text { Factor } \\
4\end{array}$ & $\begin{array}{l}\text { Factor } \\
5\end{array}$ & $\begin{array}{l}\text { Factor } \\
6\end{array}$ & $\begin{array}{c}\text { Factor } \\
7\end{array}$ \\
\hline \multicolumn{8}{|c|}{ Fashion-conscious consumers (Factor 1 ) } \\
\hline Fashion clothing means a lot to me & .826 & .067 & .139 & .151 & .020 & .065 & .023 \\
\hline I am an experienced user of fashion clothing & .851 & .048 & .046 & .191 & .055 & -.004 & .070 \\
\hline Fashion clothing is a significant part of my life & .803 & .089 & .104 & .210 & .080 & -.026 & .046 \\
\hline I usually dress for fashion & .851 & .121 & .085 & .101 & .059 & -.019 & .067 \\
\hline I am interested in fashion clothing & .859 & .138 & .101 & .158 & .055 & .093 & .032 \\
\hline I go shopping to keep up with the trends & .776 & .146 & .071 & .103 & .017 & .115 & .001 \\
\hline I am very familiar with fashion clothing & .821 & .117 & .063 & .130 & .087 & .077 & .092 \\
\hline I feel I know a lot about fashion clothing & .849 & .156 & .073 & .127 & .066 & .045 & .114 \\
\hline I would classify myself as an expert on fashion clothing & .831 & .111 & .072 & .074 & .052 & .050 & .132 \\
\hline For me fashion clothing is an important product & .842 & .138 & .185 & .136 & .045 & .108 & -.012 \\
\hline \multicolumn{8}{|c|}{ Hedonistic consumers (Factor 2) } \\
\hline Shopping for clothing is not a pleasant activity for me & -.054 & .750 & .103 & -.035 & .029 & .105 & .088 \\
\hline $\begin{array}{l}\text { Going shopping for clothing is one of the enjoyable activities in my } \\
\text { life }\end{array}$ & .155 & .770 & .036 & .083 & .075 & .070 & -.052 \\
\hline I enjoy shopping just for the fun of it & .087 & .727 & -.034 & .130 & -.011 & .047 & -.050 \\
\hline I do my shopping quickly & .092 & .798 & .091 & -.012 & .017 & .067 & -.078 \\
\hline I don't waste my time just shopping & .173 & .853 & .028 & .003 & .019 & .045 & .045 \\
\hline Shopping for clothing wastes my time & .123 & .820 & .031 & .101 & -.050 & .056 & .192 \\
\hline It is worth my time to shop in these stores & .199 & .843 & .012 & .078 & .044 & -.015 & .084 \\
\hline Shopping for clothing satisfies my sense of curiosity & .187 & .851 & .036 & .000 & .047 & .014 & .033 \\
\hline \multicolumn{8}{|c|}{ Brand-conscious consumers (Factor 3 ) } \\
\hline The higher the price of clothing, the better the quality & .128 & .026 & .781 & .028 & .092 & -.008 & .107 \\
\hline Nice departments and speciality stores offer me the best clothing & .071 & .017 & .750 & .082 & .067 & -.063 & .188 \\
\hline The most advertised brands are usually very good choices & .073 & .055 & .786 & .082 & .073 & .002 & .034 \\
\hline The well-known brands of clothing are best for me & .081 & .058 & .771 & .074 & .195 & .009 & .003 \\
\hline $\begin{array}{l}\text { The more expensive brands of clothing are usually purchased by } \\
\text { choice }\end{array}$ & .130 & .035 & .740 & .167 & .046 & .066 & -.042 \\
\hline I prefer buying the best selling brands of clothing & .202 & .071 & .716 & .169 & .196 & .036 & -.004 \\
\hline \multicolumn{8}{|c|}{ Novelty-seeking consumers (factor 4$)$} \\
\hline I keep my wardrobe up to date with the changing fashion & .173 & .114 & .060 & .826 & .101 & -.032 & .112 \\
\hline Fashionable, attractive styling is very important for me & .348 & .157 & .098 & .771 & .111 & .037 & .082 \\
\hline To get variety, I shop at different stores and chose different brands & .354 & .014 & .154 & .723 & .092 & .051 & .017 \\
\hline It's fun to buy new and exciting clothing & .176 & .011 & .172 & .816 & .054 & .087 & .027 \\
\hline It's fun to buy new and exciting clothing & .181 & .037 & .167 & .736 & .096 & .112 & .031 \\
\hline \multicolumn{8}{|c|}{ Quality-conscious consumers (Factor 5) } \\
\hline Getting very good quality is important to me & .057 & -.015 & .058 & .038 & .854 & .014 & -.007 \\
\hline
\end{tabular}




\begin{tabular}{|c|c|c|c|c|c|c|c|}
\hline Factors and variable descriptions & $\begin{array}{c}\text { Factor } \\
1\end{array}$ & $\begin{array}{l}\text { Factor } \\
2\end{array}$ & $\begin{array}{l}\text { Factor } \\
3\end{array}$ & $\begin{array}{c}\text { Factor } \\
4\end{array}$ & $\begin{array}{l}\text { Factor } \\
5\end{array}$ & $\begin{array}{l}\text { Factor } \\
6\end{array}$ & $\begin{array}{c}\text { Factor } \\
7\end{array}$ \\
\hline $\begin{array}{l}\text { When it comes to purchasing clothing, I try to get the best or make } \\
\text { the perfect choice }\end{array}$ & .001 & .043 & .080 & .047 & .770 & .103 & .026 \\
\hline In general, I try to buy the best overall quality in clothing & .087 & -.046 & .148 & .073 & .837 & .053 & -.019 \\
\hline I make a special effort to choose the very best quality clothing & .072 & .070 & .160 & .123 & .755 & .087 & .050 \\
\hline My standards and expectations for clothing I buy are very high & .217 & .125 & .288 & .155 & .576 & .062 & .157 \\
\hline \multicolumn{8}{|c|}{\begin{tabular}{|c|c|c|} 
Consumers who are confused by overchoice (Factor 6) \\
\end{tabular}} \\
\hline There are so many brands to choose from that I often feel confused & .120 & .094 & -.018 & -.011 & .127 & .829 & .015 \\
\hline Sometimes, it's hard to choose which store to shop at & .136 & .048 & -.008 & .096 & .069 & .879 & .007 \\
\hline $\begin{array}{l}\text { The more I learn about clothing, the harder it seems to choose the } \\
\text { best }\end{array}$ & .033 & .048 & .089 & .074 & .059 & .867 & .015 \\
\hline All the information I get on different products confuses me & .044 & .139 & -.034 & .054 & .043 & .868 & .005 \\
\hline \multicolumn{8}{|c|}{\begin{tabular}{|l} 
\\
Habitual, brand-loyal consumers (Factor 7)
\end{tabular}} \\
\hline I have favourite brands I buy over and over & .174 & .044 & .111 & .142 & .134 & .050 & .801 \\
\hline Once I find a brand of clothing I like, I stick to it & .058 & .037 & .099 & .084 & .000 & .002 & .872 \\
\hline I go to the same stores each time I shop for clothing & .131 & .081 & -.009 & -.009 & .008 & -.008 & .855 \\
\hline
\end{tabular}

As indicated in Table 1, seven factors that represent the shopping styles of Generation $Y$ consumers were extracted. The total variance explained by the extracted factors is $70.59 \%$ indicating that the other $29.41 \%$ is accounted for by extraneous variables that do not constitute part of this study. The high percentage of variance explained also served to confirm construct validity within the scales used.

\subsection{Analysis of variance between consumers who are confused by overchoice, and age (anova)}

Age showed significant differences between consumers who are confused by overchoice $(F=5.18, p=0.006)$ and age of respondents. The analysis of variance showed no significant differences between the remaining six factors and age. The results are reported in Table 3.

Table 3: ANOVA: Confused by Overchoice and Age

\begin{tabular}{|c|c|c|c|c|c|c|}
\hline & & Sum of squares & Df & Mean square & $\mathrm{F}$ & Sig \\
\hline \multirow{2}{*}{$\begin{array}{c}\text { (Factor 1) } \\
\text { Quality-conscious consumers }\end{array}$} & Between groups & 167 & 2 & .083 & .076 & .927 \\
\hline & Within groups & 249.031 & 227 & 1.097 & & \\
\hline \multirow{2}{*}{$\begin{array}{c}\text { (Factor 2) } \\
\text { Brand-conscious consumers }\end{array}$} & Between groups & 3.840 & 2 & 1.920 & 2.205 & .113 \\
\hline & Within groups & 197.627 & 227 & .871 & & \\
\hline \multirow{2}{*}{$\begin{array}{c}\text { (Factor } 3) \\
\text { Novelty-seeking consumers }\end{array}$} & Between groups & .492 & 2 & .246 & .351 & .704 \\
\hline & Within groups & 158.996 & 227 & .700 & & \\
\hline \multirow{2}{*}{$\begin{array}{c}\text { (Factor 4) } \\
\text { Hedonic consumers } \\
\end{array}$} & Between groups & .618 & 2 & .309 & .328 & .721 \\
\hline & Within groups & 214.204 & 127 & .944 & & \\
\hline \multirow{2}{*}{$\begin{array}{c}\text { (Factor } 5) \\
\text { Consumers confused by overchoice }\end{array}$} & Between groups & 4.945 & 2 & 2.473 & 5.180 & $.006^{*}$ \\
\hline & Within groups & 108.356 & 227 & .477 & & \\
\hline \multirow{2}{*}{$\begin{array}{c}\text { (Factor 6) } \\
\text { Habitual, brand-loyal consumers }\end{array}$} & Between groups & 7.599 & 2 & 3.800 & 3.123 & .056 \\
\hline & Within groups & 276.199 & 227 & 1.217 & & \\
\hline \multirow{2}{*}{$\begin{array}{c}\text { (Factor 7) } \\
\text { Fashion-conscious consumers }\end{array}$} & Between groups & 1.187 & 2 & .594 & .501 & .606 \\
\hline & Within groups & 268.885 & 227 & 1.181 & & \\
\hline
\end{tabular}

As a result of these differences, multiple post-hoc comparisons were undertaken to establish among which age groups there were differences. Both Tukey HSD and Bonferroni tests were used to determine group differences. The multiple post-hoc comparisons are reported in Table 4. 
Table 4: Multiple Post-Hoc Comparisons - Confused by Overchoice, and Age

\begin{tabular}{|c|c|c|c|c|c|}
\hline Dependent Variable & Age & Age & $\begin{array}{c}\text { Mean } \\
\text { Difference }\end{array}$ & $\begin{array}{c}\text { Std. } \\
\text { Error }\end{array}$ & Sig. \\
\hline $\begin{array}{c}\text { Factor } 5 \\
\text { (confused by overchoice) })\end{array}$ & $\begin{array}{c}1(16-20 \text { years }) \\
(\bar{X}=4.28)\end{array}$ & $\begin{array}{c}3(25-27 \text { years }) \\
(\bar{X}=3.94)\end{array}$ & $.3488^{*}$ & .1321 & .024 \\
\cline { 2 - 6 } & $\begin{array}{c}2(21-24 \text { years }) \\
\bar{X}=4.38\end{array}$ & $\begin{array}{c}3(25-27 \text { years }) \\
(\bar{X}=3.94)\end{array}$ & .4411 & .1387 & .005 \\
\hline
\end{tabular}

As shown in Table 4 multiple post hoc tests included a comparison of four age group ranges namely 16-20, 21-24, 25-27, and 25-27 years. Results of these comparisons are examined in the last paragraph of the discussion section.

\section{Discussion}

Factor one, labelled fashion-conscious consumers, was made up of ten items and accounted for $27.01 \%$ of the variance. This dimension reflects an inclination towards innovative products and a motivation to keep up to date with new styles and fashion trends. Bakewell, Mitchell and Rothwell (2006) reported that Generation Y consumers are typically very fashionable since they like to buy new and fashionable goods to make themselves visibly fashionable. Generation $Y$ consumers are aware of fashion and show a degree of involvement, as evidenced by high loading on the following variables: "Fashion clothing means a lot to me", "I am an experienced user of fashion clothing", "I usually dress for fashion" and "I go shopping to keep up with the trends". Bakewell and Mitchell's (2003) study among UK consumers found that both adult and younger female Generation $Y$ buyers appeared to be interested in fashion. In addition, they have a desire to bolster their self-esteem through having a "cool" look by being fashionable. Another study conducted on female consumers by Hou and Lin (2006) also demonstrates similar attitudes, reporting that Taiwanese Generation $Y$ females are in general very fashionable; they like to buy new and fashionable goods in order to appear noticeably more fashionable.

Factor two was labelled hedonistic consumers, consisted of eight variables and accounted for $11.2 \%$ of the variance. Respondents scoring high on this dimension found shopping an enjoyable and pleasant activity. They do not feel that shopping is a waste of time. In addition, they gain excitement from the task of shopping, often by buying something new. Hedonic consumers are associated with the recreational shopping consciousness trait and agree that going shopping for clothing is one of the enjoyable activities in their lives, that they enjoy shopping just for the fun of it, that shopping for clothing satisfies their sense of curiosity and that shopping is an adventure for them. In contrast, the study by Leo et al. (2005) among Australian Generation Y consumers found no support for this dimension. These authors concluded that shopping is generally perceived as a task rather than leisure and that consumers attribute their lack of interest in shopping to the fact that is a waste of time. However, Jamal, Davies, Chudry and Al-Marri (2006) revealed that the primary shopping motivations, especially for clothing, were seen to be both social and utilitarian in nature. Moreover, Radder, Li and Patersen (2006) found that Chinese Generation Y individuals in South Africa view shopping as a fun activity and do not mind spending time shopping at a variety of stores and malls and purchasing the latest styles of outfits.

Factor three was labelled brand-conscious consumers, consisted of six variables and accounted for $9.28 \%$ of the variance. The item with the highest loading on this factor is the variable "The higher the price of clothing, the better the quality". This dimension measures consumers' orientation towards purchasing well-known and high-priced brands. Respondents who scored highly on this factor appear to equate higher prices with better quality. Kwan, Yeung and Au (2004) observed that brand-conscious consumers are more likely to purchase expensive international clothing labels which are fashionable. A study conducted by Lysonski, Durvasula and Zotos (1996) also found support for brandconscious consumers among various age cohorts, inclusive of Generation Y. Studies conducted by Leo et al. (2005) and Hanzaee and Aghasibeig (2008) also revealed that Generation Y consumers were both innovative and brand conscious.

Factor four was labelled novelty-seeking consumers, consisted of five variables and accounted for $7.34 \%$ of the variance. High loadings on this dimension are: "I usually have one or more outfits of the very best newest style", "I try to get a variety of fashion apparel", and "I shop at different stores and choose different brands." Item loadings on this dimension indicate that Generation $Y$ consumers are likely to look for novelty in their purchase. These results are also consistent with the findings of a study conducted by Sproles and Sproles (1990), in which novelty and fashion-conscious consumers resemble a perfectionist consumer, but with the important exception that these types of consumers may also 
have a passive and accepting characteristic. Furthermore, novelty-seeking consumers are likely to buy best-selling brands that are the latest in style at expensive stores (Mokhlis, 2009).

Factor five was labelled quality-conscious consumers, consisted of five variables and accounted for $5.41 \%$ of the variance. A majority of the respondents indicated that quality was their major consideration when making purchase decisions. The highest-loading items on this factor were: "Getting very good quality is important to me" and "In general I try to buy the best overall-quality in clothing". Respondents who scored highly on this dimension seek to maximise quality and to make the best choice. Typically, quality-conscious consumers take time to shop for the best buy and purchase their favourite brands repeatedly, presumably since these represent perceived quality for them (Bakewell \& Mitchell, 2003). These consumers exhibit the perfectionist trait because they take time to shop carefully for the best quality or for the best value for money (Sproles \& Sproles, 1990). Consistently similar results were obtained in a study conducted by Hiu, Siu, Wang and Chang (2001), which focused on Chinese consumers. Other scholars (Tai, 2005; Radder et al., 2006) also acknowledge the existence of high levels of quality-consciousness among Generation $Y$ consumers in countries such as Hong Kong and China and South Africa.

Factor six was labelled consumers who are confused by over-choice. This factor consisted of four variables and accounted for $5.21 \%$ of the variance. Respondents who scored high on this characteristic perceive that the plethora of stores and variety confuses them, making it difficult for them to arrive at the correct buying decision. In addition, product variety and product-related information available to consumers often confuses them. The findings of the current study suggest that some Generation $Y$ consumers find it difficult to select the shop from which to purchase their apparel, given the wide assortment of available brands. However, the combined traits of confusion and saving of time/money are not necessarily a very important factor among Generation Y consumers (Bakewell \& Mitchell, 2003). As revealed by Walsh, Mitchell and Hennig-Thurau (2001), consumers who are confused by overchoice are likely to experience information overload and, as a consequence, may be less able to make optimal choices. Gonen and Ozmete (2006) also reported that consumers were indecisive in terms of selecting the store to shop at and had difficulties in selecting the products to buy owing to overchoice and often indulged in careless shopping which they later regretted. Contradictory findings were reported by Leo et al. (2005), where consumers from Western cultures were shown to be more focused on specific products, compared with consumers from Eastern cultures.

Factor seven was labelled habitual, brand-loyal consumers, consisted of three variables and accounted for $5.13 \%$ of the variance. Brand-loyal consumers are those who have favourite brands and stores and have formed habits by choosing them repetitively (Bennett \& Lachowetz, 2004). Respondents who scored highly on this dimension identified themselves as consumers who possess strong feelings of loyalty, attaching themselves to a favourite brand. High scores on variables such as "I have favourite brands I buy over and over", "Once I find a brand of clothing, I like to stick to it" and "I go to the same stores each time I shop for clothing", indicate that some Generation Y consumers are habitual and brand-loyal consumers. Sproles and Sproles (1990) asserted that this dimension is associated with serious learning. This suggests that habitual consumer behaviour may emerge from careful learning experiences that lead to positive outcomes, thus reinforcing a repeated buying behaviour pattern which leads to brand loyalty

Post-hoc results revealed that differences exist between factor 5 (confused by overchoice) and the following age categories: $16-20$ years and 25-27 years; $21-24$ years and $25-27$ years. Respondents who were in the category of $16-$ 20 years of age $(\bar{x}=4.28)$ were more confused by overchoice than those in the age category of 25-27 years $(\bar{x}=3.94)$. In addition, respondents who were in the category of 21-24 years of age were more confused by overchoice $(\bar{x}=4.38)$ than those respondents who were in the category 25-27 years of age $(\bar{x}=3.94)$. These findings indicate that younger generation $Y$ consumers are more confused by overchoice than those that are relatively older. Previous research findings (Bakewell \& Bakewell, 2003) concur that younger consumers tend to experience confusion over their purchase choices. Leo et al. (2005) attribute this response to the fact that consumers are often inundated with information and have to contend with the desire to be innovative and more open to change in their purchase decisions.

\section{Conclusion}

This study focused on exploring the shopping styles of Generation $Y$ consumers and on determining the influence of age in the shopping styles. The study identified seven pertinent dimensions that characterise the shopping styles of the Generation $Y$ cohort. It emerged that Generation $Y$ consumers are quality conscious, brand conscious, novelty seekers, hedonistic, confused by overchoice, habitual, brand loyal and fashion conscious. In terms of the influence of age in the shopping styles, it was observed that younger Generation $Y$ consumers tend to be more confused by overchoice than those that are relatively older. 
The findings of this study have important research and managerial implications. To the field of research, the study makes a contribution to current literature on consumer typologies or shopping styles by proposing an implicit and explicit classification that is applicable to the Generation $Y$ cohort. To marketers, the findings of the study may assist in decision making processes in terms of the capacity to predict the purchasing behaviour of Generation $Y$ consumers. Based on this, appropriate marketing mix strategies that lead to both the satisfaction of Generation $Y$ consumers may then be developed and implemented. This obviously has further implications on meeting organisational goals in areas such as sales and profit maximisation.

\section{Limitations}

The selection of mall and shopping centre contexts and the restricted size of the sample is a limitation of the current study in terms of generalisation of the results to other regions and contexts. While the dimensions that were extracted on shopping styles were in congruence with studies undertaken in Western countries, taking into account that South Africa consists of different sub-markets which have distinct characteristics, it would also be unrealistic to generalise the findings revealed in the study to other shopping malls and other areas in the country. In addition, the study employed a nonprobability (convenience) sampling method to select the respondents, since it was difficult to obtain a sample frame of Generation Y consumers to participate in the study. This increased the study's susceptibility to high levels of sampling bias (Whitley \& Kite, 2009).

\section{Implications for Further Research}

The current study is not without implications for further research. Firstly, the study concentrated on Generation $Y$ consumers who were in the 16 to 27 age range. Future research should accommodate other generational cohorts such as Generation X so that valuable information may be obtained to segment markets and to develop appropriate marketing strategies. Secondly, since the current study used the quantitative research design, future research could consider both a qualitative and a quantitative analysis, using triangulation methodology in order to refine the results. Thirdly, similar studies could be replicated in other provinces in order to test the relevance and reliability of the scale. More research studies focusing on consumer decision-making styles representing ethnic cultures from different provinces of South Africa could produce interesting findings. Furthermore, the current study concentrated on fashion apparel. This presents an impetus for researchers to extend their studies to other product types which require extended decision making, such as highly priced products like real estate or motor vehicles.

\section{References}

Aldlaign, A. H., \& Buttle, F. A. (2002). SYSTRA-SQ: a new measure of bank service quality. Industrial Journal of Service industry Management, 13, 362-381.

Bae, S. (2004). Shopping pattern differences of physically active Korean and American university consumers for athletic apparel. Doctoral thesis. Florida: The Florida State University College of Education.

Bakewell, C. \& Mitchell, V.W. (2003). Generation Y female consumer decision-making styles. International Journal of Retail \& Distribution Management, 3(2), 95-106.

Bakewell, C., \& Mitchell, V.W. (2004). Male consumer decision-making styles. International Review of Retail, Distribution and Consumer Research, 14(2), 223-240.

Bakewell, C., Mitchell, V.W., \& Rothwell, M. (2006). UK Generation Y male fashion consciousness. Journal of Fashion Marketing and Management, 10(2), 169-180.

Bennett, G., \& Lachowetz, T. (2004). Marketing to lifestyles: action sports and Generation Y. Sports Marketing, 13(4): 239-243.

Bowles, J. (2012).The best days to hit shopping's hot spots. Themediaonline. 7 March. [online]: Available at: http://themediaonline.co.za/2012/03/the-best-days-to-hit-shoppings-hot-spots/. (6 February 2013).

Branchik, B. J. (2010). Silver dollars: the development of the US elderly market segment. Journal of Historic Research in Marketing, 2(2), 174-189.

Bush, A., Martin, C., \& Bush, V. (2004). Sports celebrity influence on the behavioral intentions of Generation Y. Journal of Advertising Research, 44, 108-118.

Cant, M., Brink, A. \& Brijball, S. (2006). Consumer behaviour. 2nd ed. Cape Town: Juta \& Co.

Chaston, I. (2009). Boomer marketing. London: Routledge.

City of Ekurhuleni. (2011). 10 year history of Ekhuruleni. [Internet]: Available at: http://www.ekurhuleni.gov.za/about-ekurhuleni/historyof-ekurhuleni.Retrieved on 5 February 2013.

Cortes, R. (2004). Generation wars. Caribbean Business, 32 (4), 18-22. 
Da Silva, R., Davies, G., \& Naude, P. (2002). Assessing the influence of retail buyer variables on the buying decision-making process. European Journal of Marketing, 36 (11), 1297-1327.

Devellis, R. F. (2003). Scale development: theory and applications. Thousand Oaks, CA: Sage.

Dhurup, M. (2008). A generic taxonomy of shopping motives among hypermarkets (hyper-stores) customers and the relationship with demographic variables. Acta Commercii, 8, 64-79.

Drakes-Bridges, E. \& Burgess, B. (2010). Personal preferences of tween shoppers. Journal of Fashion Marketing and Management, 14(4), 624-633.

Durvasula, S., Lysonski, S. \& Andrews, C.J. (1993). Cross-cultural generalizability of a scale for profiling consumer shopping styles. Journal of Consumer Affairs, 27(1), 55-65.

Fan, J.X., \& Xiao, J.J. (1998). Consumer decision-making styles of young adult Chinese. The Journal of Consumer Affairs, 32(2), 275-294.

Gehrt, K.C., \& Shim, S. (1998). A shopping orientation's segmentation of French consumers: implications for catalog marketing. Journal of Interactive Marketing, 12(4): 34-46.

Gonen, E., \& Ozmete, E. (2006). Decision-making styles of young Turkish consumers. Journal of the Home Economics, 13(1), 26-33.

Gutman, J., \& Mills, M.K. (1982). Fashion life style, self-concept, shopping orientation and store patronage: An integrative analysis. Fashion Life Style, 58(2), 64-83.

Hafstrom, J.L., Chae, J.S., \& Chung, Y.S. (1992). Consumer decision-making styles: comparison between United States and Korean young consumers. The Journal of Consumer Affairs, 26(1), 146-158.

Hair, J. F., Black, B., Babin, B., Anderson, R. E., Tatham, R. L., \& Black, W. C. (2010).Multivariate data analysis: a global perspective. NY: Pearson Education Inc.

Hanzaee, K.H., \& Aghasibeig, S. (2008). Generation Y female and male decision-making styles in Iran. Distribution and Consumer Research, 18(5), 521-537.

Hiu, A., Siu, N., Wang, C.C.L., \& Chang, L.M.K. (2001). An investigation of decision-making styles of consumers in China. Journal of Consumer Affairs, 35(2), 326-345.

Hollywood, L. E., Armstrong, G.A., \& Durkin, M.G. (2007). Using behavioural and motivational thinking in food segmentation. International Journal of Retail \& Distribution Management, 35(9), 691-702.

Hou, C., \& Lin, Z.H. (2004). Shopping styles of working Taiwanese females. National Chung Cheng University running paper. Taiwan.18.

Hughes, A. (2008). Y and how: Strategies for reaching the elusive Generation Y consumer. Honours College Theses. [online]. Available at: http://digitalcommons.pace.edu/honorscollege theses/74. (7 February 2013).

Jamal, A., Davies, F., Chudry, F., \& Al-Marri, M. (2006). Profiling consumers: a study of Qatari consumers shopping motivations. Journal of Retailing and Consumer Services, 13, 67-80.

Jin, B., \& Kim, J.O. (2003). A typology of Korean discount shoppers: shopping motives, store attributes, and outcomes. International Journal of Service Industry Management, 14(4), 396-419.

Kaltcheva, V., \& Weitz, B. (2006). When should a retailer create an exciting store environment? Journal of Marketing, 70(1), 107-118.

Kennedy, L. (2001). The up and coming generation. Retail Merch, 41(8), 66-73.

Kim, J. (2003). College students' apparel impulse buying behaviours in relation to visual merchandising. Unpublished master's thesis. American Intercontinental University, Los Angeles.

Kim, J., \& Park, J. (2005). A consumer shopping channel extension model: attitude shift toward the online store. Journal of Fashion Marketing and Management, 9(1), 106-121.

Kothari, C. R. (2009). Research methodology: methods and techniques. $2^{\text {nd }}$ ed. New Delhi: New Age International.

Koutras, E. (2006). The use of mobile phones by Generation Y students at two universities in the city of Johannesburg. Master's Dissertation. Pretoria: UNISA.

Kwan, C. Y., Yeung, K.W., \& Au, K.F. (2004). Decision-making behaviour toward casual wear buying: A study of young consumers in mainland China. Journal of Management \& World Business Research, 1(1), 1-10.

Kwan, C.Y., Yeung, K.W., \& Au, K.F. (2008). Relationship between consumer decision-making styles and lifestyle characteristics: Young fashion consumers in China. Journal of the Textile Institute, 99(3), 193-209.

Laermer, R., \& Simmons, M. (2007). Punk marketing. New York: Harper Collins.

Lee, J. (1998). Shopping orientations, purchase criteria and consumption patterns as an outcome of the acculturation process among female Korean-American consumers. Unpublished doctoral thesis. University of Texas Tech, Texas.

Leo, C., Bennett, R., \& Hartel, C.E.J. (2005). Cross-cultural differences in consumer decision-making styles. Cross-Cultural Management, 12(3), 32-62.

Liljander, V., Polsa, P., \& Van Riel, V. (2009). Modelling consumer responses to an apparel store brand: Store image as a risk reducer. Journal of Retailing and Consumer Services, 16, 281-290.

Lysonski, S., Durvasula, S., \& Zotos, Y. (1996). Consumer decision-making styles: a multi-country investigation. European Journal of Marketing, 30(12), 10-21.

Ma, Y.J., \& Niehm, L.S. (2006). Service expectation of older generation Y customers: an examination of apparel retail setting. Journal of Managing Service Quality, 16(6), 620-640.

Malhotra, N. K. (2007). Marketing research: an applied orientation. $2^{\text {nd }}$ ed. New Jersey, Upper Saddle River: Prentice-Hall.

Malhotra, N. K. (2009). Marketing research: an applied orientation. 6rd ed. Eaglewood Cliffs, NJ: Prentice- Hall. 
Martin, C.A., \& Turley, L.W. (2004). Malls and consumption motivation: an exploratory examination of older Generation Y consumers. International Journal of Retail \& Distribution Management, 32(9), 464-475.

Mcdonald, W.J. (1993). The roles of demographics purchase histories, and shopper decision-making styles in predicting consumer catalog loyalty: Journal of Direct Marketing, 7(3), 55-64.

Mckay, L. (2008). The matured endure. Customer Relationship Management, 12(11), 40-44.

Mishra, A.A. (2010). Consumer decision-making styles and young-adult consumers: an Indian Exploration. Isleme Arastirmalari Dergisi, $8(2), 45-62$.

Mokhlis, S. (2009). An investigation of consumer decision-making styles of young-adults in Malaysia. International Journal of Business and Management, 4(4), 140-155.

Morton, L. P. (2002). Targeting Generation Y. Public Relations, 47(2), 46-48.

Neal, C., Quester, P., \& Hawkins, D.J. (2004). Consumer behaviour: implications for marketing strategy. 6 ${ }^{\text {th }}$ ed. Sydney: McGraw-Hill.

Noble, S. M., Haytko, D. L., \& Phillips, J. (2009). What drives college-age Generation Y consumers. Journal of Business Research, 62 , 617-628.

Norris, M., \& Lecavalier, L. (2009). Evaluating the use of exploratory factor analysis in Developmental Disability Psychological Research. Journal of Autism and Developmental Disorders, 40 (1), 8-20.

Oh, J., \& Fiorito, S.S. (2002). Korean women's clothing brand loyalty. Journal of Fashion Marketing and Management, 6(3), $206-222$.

Parasuraman, A., Zeithaml, V. \& Berry, L. (1988). A multiple-item scale for measuring customer perceptions of service quality. Journal of Retailing, 64(1), 12-40.

Parker, R.S., Hermans, C.M., \& Schaefer, A.D. (2004). Fashion consciousness of Chinese, Japanese and American teenagers. Journal of Fashion Marketing and Management, 8 (2), 176-186.

Pentecost, R., \& Lynda, A. (2010). Fashion retailing and the bottom line: the effects of generational cohorts, gender, fashion fanship, attitudes and impulse buying on fashion expenditure. Journal of Retailing and Consumer Services, 17 (1), 43-52.

Pett, M. A., Lackey, N. R., \& Sullivan, J. J. (2003). Making sense of factor analysis: the use of factor analysis for instrument development in health care research. Thousand Oaks: Sage.

Presser, S., Couper, M. P., Lessler, J. T., Martin, J., Rothgeb, J. M., \& Singer, E. (2004). Methods for testing and evaluating survey questions. Public Opinion Quarterly, 68 (1), 109-130.

Radder, L., LI, Y., \& Pietersen, J. J. (2006). Decision-making styles of young Chinese, Motswana and Caucasian consumers in South Africa: an exploratory study. Journal of Family Ecology and Consumer Sciences, 34, 20-31.

Radhakrishna, R. B. (2007). Tips for developing and testing questionnaires/instruments.Journal of Extension, 45(1). [online]: Available at:http://www.joe.org/joe/2007february/tt2.php. (21 January 2013)

Rempel, C. (2009). Marketing to different generations. Security Dealer \& Integrator, 31(2), 34-36.

Rosenburg, J. (2008). Mind your generation. Journal of Property Management, 73(6), 41-44.

Santos, J.R.A. (1999). Chronbach's Alpha. a tool for assessing the reliability of scale. [online] Available at: http://www.joe.org/joe/1999.april/tt3. (23 January 2013).

Schewe, C., \& Meredith, G. (2004). Segmenting global markets by generational cohorts: Determining motivations by age. Journal of Consumer Behaviour 4, 51-63.

Schiffman, L. G., \& Kanuk, L. L. (2010). Consumer behaviour.10th ed. Upper Saddle River, New Jersey: Prentice Hall.

Shoham, A., \& Dakalas, V. (2003). Family consumer shopping in Israel: the role of teens and parents. Journal of Consumer Marketing, 20(3), 238-251.

Sproles, E.K., \& Sproles, G.B. (1990). Consumer decision-making styles as a function of individual learning Styles. The Journal of Consumer Affairs, 24(1), 134-147.

Sproles, G.B., \& Kendall, E.L. (1986). A methodology for profiling consumer's decision-making styles. The Journal of Consumer Affairs, 20(2), 267-279.

Tai, S.H.C. (2005). Shopping styles of working Chinese females. Journal of Retailing and Consumer Services, 12(3), $191-203$.

Truman, R.( 2007).The why Generation. B \& T Weekly, April 27. p.22. Twelve By Twelve: Forever 21's Upscale Venture. June 19. [online]. Available at: http://fashioninvestor.blogspot.com/2007/06/twelveby-twelve-forever-21s-upscale.html. (13 February 2013).

Tustin, D. H., Ligthelm, A. A., Martin, J. H., \& Van Wyk, H. D. J. (2005). Marketing research. Cape Town: University of South Africa.

Walsh, G., Mitchell, V.W., \& Hennig-Thurau, T.H. (2001). German consumer decision-making styles. The Journal of Consumer Affairs, 35(1), 73-95.

Westbrook, R. A., \& Black, W. C. (1985). A motivation-based shopper typology. Journal of Retailing, 61(1), 78-103.

Williams, K. C., \& Page, R. A. (2011). Marketing to the generations. Journal of Behavioral Studies in Business, 3, 1-17.

Whitley, B.E., \& Kite, M. E. (2009). The psychology of prejudice and discrimination. Hampshire: Cengage Learning.

Zeng, Y. (2008). An investigation of decision-making styles of Chinese college student online apparel shoppers. Master's degree. Unpublished Thesis, Louisiana State University and Agricultural and Mechanical College, Louisiana, USA. 